\title{
PENGGUNAAN METODE PEMBELAJARAN CONCEPT MAPPING TERHADAP KETERAMPILAN MENULIS SLOGAN
}

\begin{abstract}
Abstrak
Menulis slogan merupakan kegiatan menuangkan, menyampaikan informasi dalam bentuk kalimat pendek yang bertujuan untuk mempengaruhi atau memberikan informasi kepada khalayak umum. Tujuan penelitian ini untuk meningkatkan kemampuan siswa dalam menulis Slogan dengan Metode Concept Mapping. Untuk mencapai tujuan penelitian maka digunakan Penelitian Tindakan Kelas. Kegiatan penelitian tindakan kelas ini dilaksanakan dalam dua siklus dengan teknik pengumpulan data, lembar observasi dan lembar penilaian. Subjek penelitian adalah siswa Sekolah Menengah Pertama dengan jumlah laki-laki 15 orang dan perempuan 11 orang. Hasil penelitian ini, mulai rata-rata siklus I adalah 8,48 dengan nilai terendah 45 dan tertinggi 85. Siklus II diperoleh nilai rata-rata 90,19 dengan nilai terendah 81 dan tertinggi 97 . Hasil observasi terhadap keaktifan siswa, siklus I pertemuan pertama dan pertemuan kedua 26,92\%, siklus II pertemuan pertama dan pertemuan kedua $88,46 \%$. Peneliti menyimpulkan bahwa dengan metode pembelajaraan Concept Mapping, kemampuan siswa dalam menulis slogan dapat meningkatkan, interaksi antara guru dan siswa berlangsung lebih dekat sehingga siswa dengan mudah belajar dengan menghubungkan materi dengan kehidupan sehari-hari. Disarankan agar guru Bahasa Indonesia menggunakan metode Concept Mapping dalam pembelajaraan menulis Slogan, siswa diharapkan agar lebih aktif dalam mengikuti kegiatan pembelajaraan, peneliti selanjutnya agar melakukan penelitian tentang masalah ini untuk memperoleh hasil yang lebih akurat.
\end{abstract}

Kata kunci: Metode Pembelajaraan, Concept Mapping, Menulis Slogan

\begin{abstract}
Writing slogans is an activity of pouring, conveying information in the form of short sentences which aims to influence or provide information to the general public. The purpose of this study was to improve students' ability to write slogans with the Concept Mapping Method. To achieve the research objectives Classroom Action Research is used. This class action research activity was carried out in two cycles with data collection techniques, observation sheets, and assessment sheets. The subjects of the study were junior high school students with 15 men and 11 women. The results of this study, starting the average cycle I was 8.48 with the lowest value of 45 and the highest 85. Cycle II obtained an average value of 90.19 with the

\footnotetext{
${ }^{1}$ Prodi Bahasa Indonesia, IKIP Gunungsitoli

Alamat email: trisman_harefa@ymail.com
} 
lowest value of 81 and the highest 97 . The results of observations of student activity, the first cycle of the first meeting and the second meeting was $26.92 \%$, the second cycle was the first meeting and the second meeting was $88.46 \%$. Researchers concluded that with the Concept Mapping learning method, students' ability to write slogans could improve, the interaction between teachers and students took place more closely so that students could easily learn by connecting material with daily life. It is recommended that Indonesian Language teachers use the Concept Mapping method in learning to write slogans, students are expected to be more active in participating in learning activities, further researchers should conduct research on this problem to obtain more accurate results.

Keywords: Model Group Investigation, Writing Important Things, Interview.

\section{PENDAHULUAN}

Menulis merupakan bagian yang tidak terpisahkan dalam seluruh proses belajar yang dialami siswa. Menulis dapat didefinisikan sebagai suatu kegiatan menyampaikan pesan dengan menggunakan bahasa tulis sebagai alat medianya. Dalam kegiatan menulislah siswa dapat mengembangkan ide, gagasan, dan kreatifitas yang ada pada dirinya. Selain itu, kegiatan menulis dapat mengembangkan kreativitas yang imajinatif dan dituangkan dalam berbagai materi yang ada pada pembelajaran Bahasa Indonesia salah satunya ialah pembelajaran menulis slogan. Pembelajaraan menulis slogan merupakan pembelajaraan yang ada pada pembelajaraan Bahasa Indonesia salah satunya ialah pembelajaran menulis slogan (Suparno, 2008). Pembelajaraan menulis slogan merupakan pembelajaraan yang dapat melatih daya kreativitas serta imajinatif siswa. Selain itu, pembelajaraan slogan biasanya dimanfaatkan masyarakat luas. Sehingga pembelajaraan menulis slogan tidak hanya berguna bagi dunia pendidikan saja, namun juga berguna untuk siswa pada saat terjun kembali ke lingkungan masyarakat. Dalam kurikulum Tingkat Satuan Pendidikan 2006, Standar kompetensi Menulis Slogan adalah mengungkapkan informasi dalam bentuk rakuman, teks berita, Slogan/berita.

Perkembangan Menulis Slogan di Sekolah Menengah Pertama sekarang ini dapat dikatakan kurang baik. Berdasarkan hasil observasi peneliti kepada siswa, guru telah memberikan yang terbaik. Guru telah melakukan berbagai cara. Untuk itu solusi yang dapat dilakukan oleh peneliti dalam memecahkan permasalahan ini adalah dengan mencoba menerapkan metode pembelajaran Concept Mapping untuk dapat membantu siswa dalam melakukan kegiatan Menulis Slogan. Concept Mapping merupakan metode pembelajaran yang menghubungkan satu konsep ke konsep yang lain, sehingga membentuk suatu bagan.

Davies (2010) mengatakan concept mapping merupakan suatu pembelajaran yang didasarkan pada pembelajaran bermakna dan menggali kemampuan kognitif siswa yang menekankan pada pengetahuan atau konsep-konsep yang dimiliki siswa. Syafi'ie (1998:45) juga mengatakan bahwa, menulis adalah menuangkan gagasan, pendapat, perasaan, keinginan, dan kemauan, serta informasi ke dalam tulisan dan kemudian "mengirimkannya" kepada orang lain. Fatin, dkk (2015:55) "slogan adalah kelompok 
kata atau kalimat pendek yang menarik, mencolok, dan mudah diingat untuk memberitahukan tujuan atau visi suatu organisasi, kegiatan atau perusahaan.

\section{METODE}

Jenis penelitian ini adalah Penelitian Tindakan Kelas (PTK). Menurut Arikunto (2014) penelitian tindakan kelas merupakan kegiatan penelitian yang dilakukan terhadap sejumlah subjek yang menjadi sasaran yaitu peserta didik, bertujuan memperbaiki situasi pembelajaran di kelas agar terjadi peningkatkan kualitas pembelajaran. Metode penelitian ini adalah deskriptif yang merupakan penelitian yang benar-benar hanya memaparkan apa yang terdapat atau terjadi dalam sebuah kancah, lapangan atau wilayah tertentu (Arikunto, 2014; Zagoto, dkk., 2019; Dakhi, O., 2013)

Metode penelitian pada dasarnya merupakan cara ilmiah untuk mendapatkan data dengan tujuan dan kegunaan tertentu. berdasarkan hal tersebut terdapt empat kata kunci yang perlu diperhatikan yaitu, cara ilmiah, data, tujuan, dan kegunaan". (Sugiyono, 2012).

Lokasi penelitian ini adalah di Sekolah Menengah Pertama. Penelitian ini direncanakan pengumpulan data ini diupayakan selama 1 (satu) bulan. Pelaksanaan penelitian ini dilakukan dua siklus. Untuk menjaring data pada penelitian ini digunakan bentuk instrument penelitian, yaitu: lembar observasi dan tes menulis slogan. Lembar observasi digunakan untuk mengamati objek tindakan dan tes menulis digunakan untuk mengetahui kemampuan siswa menulis slogan. Setelah test dilakukan, selanjutnya dikoreksi, dipelajari, dan ditelaah untuk menggolongkan, mengarahkan, dan mengorganisasikan jawaban siswa. Analisis data dalam penelitian ini dengan menata secara sistematis data hasil test, dan observasi sebagai catatan lapangan. Dari hasil jawaban yang diberikan siswa maka akan diperoleh tingkat pencapaian hasil belajar. Untuk mengetahuinya peneliti melakukan pemeriksaan terhadap jawaban siswa melalui pemberian skor. Teknik analisis data dalam penelitian ini ada dua yaitu analisis data kuantitatif dan analisis data kualitatif. Teknik analisis data kuantitatif (tes menulis slogan). Setelah dilakukan analisis data kuantitatif (hasil tes menulis slogan), maka diteruskan dengan analis data kualitatif (hasil observasi).

\section{HASIL DAN PEMBAHASAN \\ Siklus I}

\section{Pertemuan Pertama}

Pembelajaran pada siklus I (Pertama), pertemuan pertama dilaksanakan pada hari Kamis dengan alokasi waktu 2x40 menit (1 kali pertemuan). Pada pelaksanaan pembelajaran, peneliti menempuh beberapa tahap sesuai dengan prosedur pelaksanaan penelitian tindakan kelas (PTK) dengan menerapkan metode pembelajaran Concept Mapping yaitu: sebagai berikut:

\section{a. Perencanaan}

Kegiatan pada perencanaan meliputi kegiatan peneliti merancang dan menyusun rencana pelaksanaan pembelajaran (RPP), menyiapkan meteri pembelajaran yaitu menulis slogan, merancang media pembelajaran yang sesuai 
berupa gambar-gambar bertema lingkungan hidup, menyiapkan daftar hadir penelitian, menyiapkan blanko observasi kepada guru mata pelajaran Bahasa dan Sastra Indonesia sebagai pengamat dan menyiapkan lembar kerja siswa.

b. Tindakan

Pada tahap tindakan, peneliti melaksanakan pembelajaran sesuai dengan langkah-langkah metode pembelajaran Concept Mapping (Zagoto, dkk., 2018; Sarumaha, 2018; Dakhi, O., 2013), yakni, sebagai berikut:

1) Menyediakan bahan bacaan. Bahan bacaan dimaksud adalah lingkungan hidup;

2) Menyediakan media pembelajaran berupa potongan-potongan kartu yang berisikan gambar yang berkaitan dengan lingkungan;

3) Siswa mengurutkan gambar-gambar tersebut sehingga saling berhubungan;

4) Menyusun gambar yang telah diurutkan di atas kertas karton dengan menggunakan kata penghubung, sehingga membentuk suatu peta konsep. Berdasarkan peta konsep tersebut, siswa dituntun untuk membuat sebuah slogan.

\section{c. Observasi}

Pada tahap observasi, guru pengamat mengamati aktifitas siswa dan peneliti selama proses pembelajaran menulis slogan belagsung pada siklus 1 pertemuan pertama. Hasil pengamatan ini akan di gabung pada siklus 1 pertemuan kedua. Namun terdapat kelemahan dan kelebihan selama pembelajaran berlangsung :

1) Kelebihan siswa adalah : adanya antusias siswa memberikan pertanyaan terhadap materi pembelajaran menulis slogan, terjalinnya interaksi yang baik antar peneliti dan siswa dalam pembelajaran, antara siswa saling memberikan solusi terhadap hal- hal yang kurang jelas terhadap hal- hal yang kurang jelas terhadap materi pembelajaran:

2) Kelemahan siswa adalah: tidak semua siswa aktif dalam pembelajaran yang di sampaikan oleh peneliti, sebagian siswa yang menggangu temannya, terjadinya perbedaan pendapat dalam menyelesaikan permasalahan yang ada sehingga memerlukan waktu yang relatif lama. Masih banyak siswa yang kurang aktif memberikan pertanyaan. Siswa kesulitan dalam memahami peta konsep yang telah dijelaskan dan adanya siswa yang keluar masuk ruangan sehingga menggangu konsentrasi teman yang lain Selama proses pembelajaran.

3) Kelebihan peneliti yaitu: sebelum menyampaiakan materi pembelajaran peneliti terlebih dahulu mengarahkan siswa dan mengarahkan siswa dan memotivasi siswa terhadap pembelajaran. Sebelum peneliti menjelaskan materi yang akan di sampaikan terlebih dahulu memberitauhkan tujuan dari materi tersebut bahkan mengaitkan kehidupan sehari- hari. Peneliti menjelaskan materi dengan terperinci dan tidak terlalu fokus pada catatan, peneliti juga memberikan kesempatan kepada siswa menanyakan hal-hal yang kurang di pahami;

4) Kelemahan penelitian yaitu: dalam menyampaikan materi peneliti terlalau cepat sehingga perserta didik sulit menangkap arah pembicaraan dalam kegiatan pembelajaran, peneliti kurang mampu menguasai dan mengkondisikan kelas. Peneliti kuang mampu memberikan penghargaan terhadap siswa ketika mampu menjawab atau menangapi pertanyaan dari peneliti. Pemberian applause atau 
penghargaan bias membangkitkan semangat siswa, sehingga hal tersebut perlu di perhatikan oleh peneliti dalam proses pembelajaran.

d. Refleksi

Kegiatan yang dilakukan dalam refleksi ini adalah memperbaiki kelemahankelemahan yang terjadi di dalam proses pembelajaran pada siklus 1 pertemuan pertama baik kelemahan peneliti maupun kelemahan siswa. Maka, peneliti perlu mengadakan refleksi dengan memberikan penghargaan kepada siswa ketika siswa mampu menaggapi pertanyaan dari penelit, peneliti mengurangi kecepatan saat menjelaskan sehingga siswa mampu memahami dan menangkap materi pembelajaran dari peneliti, peneliti memberikan perhatian kepada siswa yang kurang mampu dalam prose pembelajaran

\section{Pertemuan Kedua}

a. Perencanaan

Kegiatan dalaam perencanaan ini adalah peneliti kembali mempersiapakan perangkat pembelajaran yang berhubungan dengan materi menulis slogan, mempersiapakan kembali daftar hadir, lembar kerja siswa, contoh slogan, media pembelajaran yaitu potongan-potongan gambar lingkungan, kertas karton, lem dan gunting; dan tes menulis slogan.

b. Tindakan

Kegiatan pada tindakan ini adalah peneliti menerapkan langkah-langkah metode pembelajaran concept mapping terhadap keterampilan menulis slogan, yaitu:

1) Peneliti mengulas kembali penjelasan tentang langkah-langkah metode pembelajaran concept mapping yang telah dijelaskan oleh peneliti pada pertemuan pertama, agar siswa tidak lupa kegiatanyang akan mereka laksanakan:

2) Peneliti meminta kepada siswa untuk membentuk lima kelompok belajar dari yang terdiri dari 5-6 orang;

3) Peneliti membagikan media pembelajaran kepada masing-masing kelompok, yang terdiri dari kertas karton, potongan-potongan gamabar lingkuangan, lem dan gunting;

4) Peneliti memberikan waktu kepada siswa untuk menuangkan kreativitas nya dalam menyusun media pembelajaran yang telah di bagikan sehingga membentuk peta konsep, sesuai dengan penjelasan peneliti sebelum nya;

5) Peneliti mendampingi dan mengarahkan siswa selama proses pembelajaran berlangsung;

6) Setelah peta konsep masing-masing kelompok telah selesai , maka setiap siswa di persilahkan menulis sebuah slogan yang sesuai dengan pera konsep yang telah di buat oleh kelompok nya;

7) Peneliti mengumpulkan hasil kerja siswa ;

8) Penelit menyimpulkan pembelajaran; 
9) Peneliti melakukan refleksi atau penilaian atau kegiatan yang sudah di laksanakan;

10) Peneliti memberi umpan balik terhadap proses hasil belajar;

11) Peneliti menutup pembelajaran dan kembali menyapa siswa;

c. Observasi

Pada tahap observasi, guru pengamat mengamati aktifitas siswa dan peneliti selama proses pembelajaran menulis slogan belagsung pada siklus 1 pertemuan kedua.

d. Refleksi

Kegiatan yang dilakukan dalam refleksi ini adalah memperbaiki kelemahankelemahan yang terjadi di dalam proses pembelajaran pada siklus 1 pertemuan pertama baik kelemahan peneliti maupun kelemahan siswa. Maka, peneliti perlu mengadakan refleksi dengan memberikan penghargaan kepada siswa ketika siswa mampu menaggapi pertanyaan dari peneliti, peneliti mengurangi kecepatan saat menjelaskan sehingga siswa mampu memahami dan menangkap materi pembelajaran dari peneliti, peneliti memberikan perhatian kepada siswa yang kurang mampu dalam prose pembelajaran.

Tabel 1. Persentase pengunaan metode pembelajaran concept mapping terhadap keterampilan pada Siklus I

\begin{tabular}{|c|c|c|c|}
\hline $\begin{array}{c}\text { Interval persentase } \\
\text { tingkat penguasaan }\end{array}$ & Kriteria penilaian & Jumlah siswa & presentase \\
\hline $96-100$ & Sempurna & - & - \\
\hline $86-95$ & Baik sekali & - & - \\
\hline $76-85$ & Baik & 5 & $19,23 \%$ \\
\hline $66-75$ & Cukup & 8 & $30,77 \%$ \\
\hline $56-65$ & sedang & 3 & $11,54 \%$ \\
\hline $46-55$ & Hampir sedang & 7 & $26,92 \%$ \\
\hline $33-45$ & kurang & 3 & $11,54 \%$ \\
\hline $26-35$ & Kurang sekali & - & - \\
\hline $16-25$ & buruk & - & - \\
\hline $1-15$ & Buruk sekali & - & $100 \%$ \\
\hline \multicolumn{2}{r|}{ Jumlah } & 26 orang & \\
\hline
\end{tabular}

\section{Siklus II}

\section{Pertemuan Pertama}

a. Perencanaan

Kegiatan pada perencanaan meliputi kegiatan peneliti merancang dan menyusun rencana pelaksaan pembelajaan (RPP) dengan menyesuaikan perbaikanperbaikan dari siklus I (pertama) yang mempengaruhi hasil belajar siswa, menyiapkan materi pembelajaran yaitu menulis slogan, merancang media pembelajaran yang sesuai berupa gambar-gambar bertema lingkungan hidup, menyiapkan daftar hadir penelitian, menyiapkan blangko obserfasi pada guru 
pembelajaran Bahasa Dan Sastra Indoneia sebagai pengaman dan menyiapkan lembar siswa.

b. Tindakan

Berdasarkan rencana pelaksanaan pembelajaran adalah (RPP), maka tahap tindakan dalam siklus di rencanakan sebagai berikut :

1) Penelitian mengawali pembelajaran dengan menyapa siswa dan mengabsen siswa;

2) Penelitian menyampaikan standar kopetensi dasar, indicator, KKM dan tujuan pembelajaran pada siswa sebagai dasar kepada siswa;

3) Peneliti menjelaskan materi menulis slogan;

4) Peneliti mengulas kembali langka-langkah model pembelajaran concep mapping, dan menjelaskan lebih terperinci yaitu:

a) Menyidiakan bahan bacaan. Bahan bacaan yang dimaksud adalah lingkuingan hidup

b) Menyediakan media pembelajaran berupa potongan-potongan kartu yang berisikan gambar-gambar yang berkaitan dengan lingkungan

c) Siswa mengurutkan gambar-gambar tersebut sehingga saling berhubunga

d) Menyusun gambar yang telah diurutkan diatas kertas karton dengan menggunakan kata penghubung, sehingga membentuk suatu peta konsep

e) Berdasarkan peto konsep tersebut, siswa dituntut untuk membentuk sebuah slogan

5) Setelah selesai menyampaikan materi, minta siswa untuk membaca hasil catatannya

6) Berikan klarifikasi (penjelasan)

7) Peneliti menutup pembelajaran dan menyapa siswa

c. Observasi

Pada tahap observasi, guru pengaman mengamati seluruh aktifitas siswa dan peneliti selama kegiatan pembelajaran mengajar berlangsung. Hasil pengmatan yang dilaksanakan pada hasil observasi siklus II perttemuan kedua namun terdapat pada beberapa kelemahan pada proses pembelajaran, yaitu:

1) Kelebihan siswa yaitu : adanya peningkatan terhadap keberanian siswa dalam menyampaikan pendapat atau menanggapi materi pembelajaran menulis slogan, saling menghargai teman dalam menyampaikan pendapat. Siswa termotivasi mengetahui metode pembelajaran Concept Mapping terhadap menulis slogan, siswa atusiasi dalam proses pembelajaran

2) Kelemahan siswa yaitu : masih terdapat beberapa siswa yang belum memahami pengertian slogan dengan baik. Adanya siswa yang ingin mempertahanakan pendapatnya masing-masing.

3) Kelebihan peneliti yaitu : adanya komunikasi yang positif antara peneliti dan siswa selama proses pemebelajaran berlangsung. Peneliti mampu membangkitkan semangat belajar siswa dan memberikan penghargaan (applause) jika siswa menjawab pertanyaan secara benar. Peneliti mampu mengkondisikan dan mampu menguasai kelas. 
4) Kelemahan peneliti yaitu : peneliti kurang maksimalkan waktu dengan sebaikbaiknya. Volume suara peneliti dalam menyampaikan materi kurang jelas sehingga siswa yang berada dibelakang tidak mendengar peneliti secara jelas.

d. Refleksi

Setelah dilaksanakan pembelajaran, maka peneliti mengadakan refleksi. Adapun beberapa refleksi yang dilakukan peneliti adalah peneliti memaksimalkan volume suaranya agar seluruh siswa dapat mendengarkan dengan jelas, peneliti memaksimalkan mungkin, member penjelasan yang mendetail tentang pengertian slogan kepada siswa. Selanjutnya peneliti melanjutkan pertemuan berikut yaitu pada pertemuan kedua.

\section{Pertemuasn kedua}

a. Perencanaan

Kegiatan dalam perencaaan ini adalah peneliti kembali mempersiapkan perangkat pembelajaran yang berhubungan dengan materi menulis slogan, mempersiapkan kembali daftar hadir, lembar kerja siswa, contoh slogan, media pembelajaran yaitu potongan-potongan, gambar lingkungan, kertas karton, lem dan gunting, dan tes menulis slogan.

b. Tindakan

Kegiatan pada tindakan ini adalah peneliti menerapkan langkah-langkah metode pembelajaran (Concept Mapping) terhadap keterampilan slogan.

1) Peneliti mengulas kembali penjelasa tentang langkah-langakah metode pembelajaran (Concept Mapping) yang telkah dijelaskan oleh peneliti pada pertemuan pertama, agar siswa tidak lupa kegiatan yang akan mereka laksanakan.

2) Peneliti meminta kepada siswa untuk membentuk 5 kelompok belajara yang terdiri dari 5-6 orang;

3) Peneliti membagikan media pembelajaran pada masing-masing kelompok, yang terdiri dari kertas karton, potongan-potongan gambar lingkungan, lem dan gunting;

4) Peneliti member waktu kepada siswa untuk menuangkan kreativitasnya dalam menyusun media pembelajaran yang telah dibagikan sehingga membentuk peta konsep, sesuai dengan penjelasan peneliti sebelumnya

5) Peneliti mendampingin dan mengarahkan siswa selama proses pembelajaran berlangsung

6) Setelah peta konsep masing-masing telah menyelesaikan maka setiap siswa dipersilahkan menulis sebuah sloga sesuai dengan pera konsep yang telah dibuat oleh kelompoknya

7) Peneliti mengumpulkan hasil kerja siswa

8) Peneliti menyimpulakn pembelajaran

9) Peneliti melaksanakan refleksi ataupun penilaian terhadap kegiatan yang sudah dilaksanakan 
10) Peneliti memberikan umpan balik terhadap proses dan hasil belajar

11) Peneliti menutup pemebelajaran dan kembali menyapa siswa

c. Observasi

Ada dua hal yang perlu diperhatikan dalam kegiatan observasi ini, yaitu mengamati aktivitas siswa dan peneliti. Hasil observasi siklus ke II pertemuan pertama dan kedua adalah sebagai berikut:

1) Hasil observasi siswa

a. Siswa yang aktif dalam pembelajaran adalah 23 dari 26 jumlah siswa keseluruhan $88,46 \%$

b. Siswa yang tidak aktif adalah 3 orang dari 26 jumlah siswa keseluruhan yaitu $11,54 \%$

2) Hasil observasi untuk peneliti

a. Kinerja peneliti yanh terlaksana yaitu $100 \%$

b. Kinerja peneliti yang tidak terlaksana

\section{d. Refleksi}

berdasarkan hasil pengolahan data tes menulis slogan, nilai rata-rata yang diperoleh siswa pada siklus kedua yaitu 90,19 dengan jumlah nilai 2345. Melalui hasil olahan data tersebut dinyatakan kemampuan siswa menulis slogan melalui metode pembelajaran (Concept Mapping) mengalami peningkatan pada siklus I (pertama) sebelumnya data telah mencapai target keberhasilan yang ditentukan yaitu tercapainya kriteria ketutasan minimum (KKM) yaitu 72. Jadi hasil belajar hasil siklus ke II dapat disimpulkan bahwa kemampuan menulis slogan melalui metode pembelajaran (Concept Mapping) siswa menengah pertama tertingkatkan. Maka, persentase kemampuan siswa menulis slogan dapat diklasifikasikan seperti taber berikut:

Tabel 2. Persentase pengunaan metode pembelajaran concept mapping terhadap keterampilan pada Siklus II

\begin{tabular}{|c|c|c|c|}
\hline $\begin{array}{c}\text { Interval prsentase } \\
\text { tingkat penguasaan }\end{array}$ & Kriteria penilaian & Jumlah siswa & presentase \\
\hline $96-100$ & Sempurna & - & - \\
\hline $86-95$ & Baik sekali & - & - \\
\hline $76-85$ & Baik & 8 & $30,77 \%$ \\
\hline $66-75$ & Cukup & 3 & $11,54 \%$ \\
\hline $56-65$ & sedang & 5 & $19,23 \%$ \\
\hline $46-55$ & Hampir sedang & 7 & $26,92 \%$ \\
\hline $33-45$ & kurang & 3 & $11,54 \%$ \\
\hline $26-35$ & Kurang sekali & - & - \\
\hline $16-25$ & buruk & - & - \\
\hline $1-15$ & Buruk sekali & - & $100 \%$ \\
\hline \multicolumn{2}{|r|}{ Jumlah } & 26 orang & \\
\hline
\end{tabular}




\section{Pembahasan}

Pembahasan hasil temuan penelitian ini dimaksudkan untuk mengetahui lebih jauh temuan-temuan penelitian sebagaimana dikemukakan pada bagian-bagian sebelumnya. Dalam pembahasan temuan penelitian ini di dasarkan pada tujuan penelitian, kajian pustaka, temuan sebelumnya dan keterbatasan penelitian. Agar penelitian ini lebih terarah, maka urutan pembahasan dalam penelitian ini adalah mengungkapkan kembali permasalahan pokok penelitian, memberikan jawaban umum atas permasalahan penelitian, analisis dan penafsiran temuan-temuan, perbandingan temuan dengan teman sebelumnya serta keterbatasan analisis dan tafsiran temuan,

\section{Permasalahan Pokok}

Sebagaimana yang telah diungkapkan pada Bab I, bagian sub-bab bahwa persoalan utamand alam penelitian ini adalah menulis slogan melalui metode pembalajaran Concept Mappin. Berdasarkan permasalahan tersebut dirumuskan peningkatan kemampuan siswa menulis slogan tentang lingkungan hidup melalui metode pembelajaran (Concept Mapping) disekolah menengah pertama. Untuk memecahkan massalah tersebut dilakukan dengan penelitian tindakan kelas (PTK) dan juga berdasarkan teori metode pembelajaran (Concept Mapping) dan teori menulis sloga, maka tujuan permasalahan dan penelitian ini adalah untuk mendapatkan informasi adanya tidaknya peningkatan kemampuan siswa menulis slogan melalui metode pembelajaran (Concept Mapping) . setelah melakukan peneliti dengan desain kualitatif, diperoleh sejumlah informasi tentang adanya peningkatan kemampuan siswa menulis slogan melalui metode epmbelajaran (Concept Mapping) siswa dikelas.

\section{Jawaban Umum Atas Permasalahan Pokok Penelitian}

Berdasarkan penerapan metode pembelajaran Concept Mapping yang dilakukan oleh peneliti dalam proses belajar mengajar menulis khususnya Slogan, maka jawaban umum yang dapat diberikan adalah dengan menggunakan metode pembelajaran Concept Mapping dapat meningkatkan kemampuan siswa menulis slogan. Jawaban umum yang dapat diberikan terhadap kemampuan siswa menulis slogan adalah secara umum tingkat kemampuan siswa pada awalnya masih tergolong rendah karena selama ini materi menulis slogan bagi siswa tidak sesuai dengan kenyataan dan permasalahan di kelas. Setelah diterapkan metode pembelajaran Concept Mapping maka kemampuan siswa menulis slogan mewningkat, dengan ratarata kemampuan siswa pada siklus I yaitu 68,48 dan siklusb II terjadi peningkatan menjadi 90,19.

\section{Analisis dan Penafsiran Temuan Penelitian}

Analisis dan penafsiran temuan penelitian selama berlangsungnya proses pembelajaran menulis slogan khususnya slogan yang bertema lingkungan hidup melalui metode pembelajaran Concept Mapping, dapat diketahui melalui pengolahan 
data, baik data kuantitatif berupa tes menulis slogan maupun data kualitatif berupa hasil observasi. Pada siklus I (pertama) ditemukan hasilnya keaktifan siswa yaitu $26,92 \%$ dan kinerja peneliti yang terlaksana yaitu $90 \%$ sehingga didapatkan nilai rata-rata hasil belajar siswa $=68,48$. Hasil belajar siswa pada siklus I (pertama) terlihat masing kurang, karena masih terdapat siswa yang kurang aktif dan termotivasi dalam belajar. Hal ini disebabkan karena (1) penguasaan siswa terhadap materi pembelajaran masih kurang; (2) siswa masih kurang termotivasi dalam mengajukan pertanyaan terhadap materi yang disampaikan oleh peneliti dan siswa tidak memiliki percaya diri untuk menanyakan materi yang belum jelas kepada guru serta ragu-ragu menaggapi pertanyaan siswa lain; (3) siswa masih kurang mampu dan terampil dalam menulis slogan. Dari kelemahan-kelemahan tersebut, peningkatan kemampuan siswa masih belum memuaskan dan motivasi siswa dalam belajar masih kurang. Oleh karena itu, perlu diadakan perbaikan lagi untuk dilanjutkan pada siklus II (kedua). Dari proses pembelajaran siklus II ditemukan hasil telah terjadi peningkatan yang signifikan. Peningkatan ini terlihat dari hasil yang diperoleh pada keaktifan siswa yaitu $88,46 \%$ dan kinerja guru yang terlaksana yaitu $100 \%$ sehingga perolehan hasil belajar nilai rata-rata $=90,19$. Berdasarkan hasil belajar yang ditemukan pada penelitian ini, maka tingkatan kemampuan siswa menulis slogan khususnya slogan lingkungan hidup melalui metode pembelajaran Concept Mapping.

4. Perbandingan Temuan Penelitian dengan Temuan Lain

Wahyuni tahun 2012, meneliti tentang Peningkatan Kemampuan Menulis Slogan melalui Metode Kontruktivisme Pada Siswa Kelas V SDN Slarang Lor 03. Pada penelitian ini ditemukan bahwa kemampuan siswa dalam menulis slogan meningkat.peningkatan ini dapat dilihat dari nila rat-rata siklus I $(72,02)$ dan siklus II (79,32). Habbibah tahun 2014, penerapan Concept Mapping Untuk meningkatkan pemahaman konsep matematika pada siswa kelas VII Csemester Gasal SMP Muhammadiyah 2 sukarta. Pada penelitian ini ditemukan bahwa penerapan concept Mapping dapatmeningkatkan pemahaman konsep belajar siswa. Hal tersebut dapat dilihat dari tercapainya indikator -indikator pemahaman konsep belajar matematika sebagai berikut: (1)menjawab pertanyaan guru dan mengerjakan soal di papan tulis secara tepat dari $23,33 \%$ sebelum tindakanmenjadi $70 \%$ pada akhir tindakan,(2) memberikan tanggapan tentang jawaban peserta didik lain lebih dari 16,67\% sebelum tindakan menjadi $66,6 \%$ pada akhir tindakan,(3) membuat kesimpulan yang meliputi mendefinisikan konsep, menemukan sifat-sifat dari konsep dan memberikan contoh dan non contoh dari konsep dari $10 \%$ sebelum tindakan menjadi 53,33\% pada akhir tindakan.

\section{Perbandingan Temuan Penelitian dan Teori}

Penelitian ini diperoleh temuan yaitu: dengan menggunakan metode pembelajaran Concept Mapping dapat meningkatkan kemampuan siswa dalam 
menulis slogan. Searah dengan pendapat Fahzurrohman (2015) bahwa metode pembelajaran Concept Mapping salah satu strategi dalam pembelajaran aktif dan diyakini dapat meningkatkan keaktifan siswa yang berpengaruh terhadap hasil belajar siswa.

6. Keterbatasan Analisis dan Penafsiran Temuan penelitian

Keabsahan temuan penelitian di lapangan pada hakikatnya tidaklah mutlak, disebabkan karena ada sejumlah keterbatasan baik dari hasil yang diperoleh,maupun dari penerapan peneliti di lokasi penelitian. Berdasarkan hasil analisis yang di temukan pada siklus I dan II pada dasarnya keterbatasan maksimal yang dicapai adalah $100 \%$ tetapi berdasarkan hasil yang di peroleh hanya $88,46 \%$ hal ini terjadi peningkatan pada siklus II. Oleh sebab itu ada beberapa keterbatasan penelitian yaitu: (a). peneliti kurang mampu mengontrol emosi siswa serta individu yang dapat menyebabkan kurangnyaperhatian siswa dalam mengikuti pembelajaran, (b). penelitian ini hanya dilaksanakan di kelas sekolah menengah pertama.

\section{KESIMPULAN}

Berdasarkan hasil temuan penelitian dan rumusan masalah penelitian yang dilaksanakan di kelas sekolah menengah pertama, menunjukkan hasil belajar siswa pada siklus I di dapatkan nilai rata-rata hasil belajar siswa $=68,48$ dengan nilai tertinggi 85 dan nilai terendaj 45. Serta keaktifan siswa yaitu 26,92\% dan kinerja peneliti yang terlaksana yaitu 90\%. Pada siklus II di temukan hasil belajar siswa meningkat secara signifikan. Peningkatan ini terlihat dari perolehan hasil belajar siswa pada siklus ini dengan rata-rata $=90,19$. Pada siklus II ditemukan nilai 79 dan nilai terendah 81 . Dengan keaktifan siswa yaitu $88,46 \%$ dan kinerja guru $100 \%$. Data ini menunjukkan bahwa hasil belajar siswa pada siklus II lebih baik dari siklus I. Dari uraian di atas, disimpulkan bahwa dengan menggunakan metode pembelajaran concept mapping dapat meningkatkan hasil belajar siswa menulis slogan khususnya slogan lingkungan hidup.

\section{SARAN}

Peneliti menyarankan guru mata pelajaran Bahasa Indonesia di sekolah menengah pertama untuk dapat menggunakan metode pembelajaran Concept Mapping sebagai variasi belajar agar siswa aktif di kelas sehingga tujuan pembelajaran dapat tercapai secara efektif dan efesien. Bagi siswa sekolah menengah pertama,peneliti menyarankan agar penelitian ini dapat dijadikan sebagai bahan dalam upaya peningkatan kualitas proses belajar mengajar di sekolah. Bagi guru peneliti menyarankan agar dapat di jadikan sebagai bahan referensi dalam menggunakan dan memilih model pembelajaran untuk meningkatkan kemapuan siswa dalam menulis. Dan bagi siswa, agar dapat dijadikan sebagai salah satu factor untuk menimbulkan motifasi dalam belajar menulis. Untuk penelitian selanjutnya, agar penelitian ini dilaksanakan lebih baik lagi termasuk dalam mendesain dan memodifikasi metode pembelajaran yang benar-benar memperbaiki proses pembelajaran. 


\section{DAFTAR PUSTAKA}

Arikunto, Suharsimi, dkk. 2014. Penelitian Tindakan Kelas. Jakarta: PT. Bumi Aksara.

Arikunto, Suharsimi. 2010. Prosedur Penelitian suatu Pendekatan Praktik. Jakarta: PT Rineka Cipta.

Dakhi, O. "Aplikasi Pendeteksian Kerusakan File Akibat Virus Dengan Menggunakan Metode Heuristic." Pelita Informatika Budi Darma, vol. 4, no. 1, pp. 35-41, 2013.

Dakhi, O. 2013. Belajar Javascript Dengan Mudah Dan Detail. Jakarta: Dapur Buku. pp. 1-202.

Davies, Martin.2010. Concept Mapping, Mind Mapping, And Argument Mapping: What Are The Different And Do They Matter?. HigherEducation. (62)(3):279-301

Fahzurrohman, Muhammad. 2015. Model-Model Pembelajaran Inovatif. Yogjakarta: Ar-Ruzz Media.

Habbibah, 2014, penerapan concept mapping untuk meningkatkan pemahaman konsep matematika pada siswa kelas VII c semester gasal smp muhammadiyah 2 surakarta, (online) http://eprints.ums. Ac.id/27935/ diakses pada 11 februari 2016.

Sarumaha, R., Harefa, D., \& Zagoto, Maria M. (2018). Upaya Meningkatkan Kemampuan Pemahaman Konsep Geometri Transformasi Refleksi Siswa Kelas XII-IPA-B SMA Kampus Telukdalam Melalui Model Pembelajaran Discovery Learning Berbantuan Media Kertas Milimeter. Jurnal Education and development, Vol.6 No.1, 90-96. https://doi.org/10.37081/ed.v6i1.668

Sugiyono. 2012. Metode Penelitian Kuantitatif Kualitatif dan R\&D. Bandung:Alfabeta.

Suparno,Yunus, 2008, keterampilan Dasar Menulis, Universitas Terbuka,Jakarta. Yunus, dkk, 2013,Kerampilan Menulis, universitas Terbuka. Tanggerang selatan.

Wahyuni, 2012. Peningkatan kemampuan menulis slogan melalui metode kontruktivisme pada siswa kelas V SDN slarang lor 03.

Zagoto, Maria M., Yarni, Nevi; Dakhi, O. (2019). Perbedaan Individu dari Gaya Belajarnya Serta Implikasinya Dalam Pembelajaran. Jurnal Review Pendidikan dan Pengajaran, 2(2), 259265.

Zagoto, Maria M. \& Dakhi, O (2018). Pengembangan Perangkat Pembelajaran Matematika Peminatan Berbasis Pendekatan Saintifik Untuk Siswa Kelas XI Sekolah Menengah Atas. Jurnal Review Pendidikan dan Pengajaran, 1(1), 157-170.

Zagoto, Maria M. (2018). Pengembangan Perangkat Pembelajaran Matematika Berbasis Realistic Mathematic Educations Untuk Siswa Kelas V Sekolah Dasar, Jurnal Education And Development, vol. 3, no. 1, p. 53, Feb. 2018. https://doi.org/10.37081/ed.v3i1.139 